\title{
Plasminogen Enhances Neuritogenesis on Laminin-1
}

\author{
Ana Gutiérrez-Fernández, ${ }^{1}$ Neill A. Gingles, ${ }^{2}$ Hongdong Bai, ${ }^{2}$ Francis J. Castellino, ${ }^{3}$ Robert J. Parmer, ${ }^{2}$ \\ and Lindsey A. Miles ${ }^{1}$ \\ ${ }^{1}$ Department of Cell Biology, Division of Vascular Biology, The Scripps Research Institute, La Jolla, California 92037, ${ }^{2}$ Department of Medicine, University \\ of California, San Diego, and Veterans Administration San Diego Healthcare System, San Diego, California 92161, and ${ }^{3}$ W. M. Keck Center for Transgene \\ Research, University of Notre Dame, Notre Dame, Indiana 46556
}

\begin{abstract}
Proteins of the plasminogen activation system are broadly expressed throughout the nervous system, and key roles for these proteins in neuronal function have been demonstrated. Recent reports have established that plasminogen is synthesized in neuroendocrine tissues, making this protein and the proteolytic activity of the product of its activation, plasmin, available at sites separated anatomically from circulating, hepatocyte-derived plasminogen. Results with plasminogen-deficient humans and mice suggest a role for plasminogen in neuritogenesis. To elucidate the role of the plasminogen activation system in these processes, the function of plasminogen during neuritogenesis and neurite outgrowth was studied. It is shown here that plasminogen participates in neuritogenesis, as plasmin inhibitors reduced both neurite outgrowth and neurite length in PC-12 cells. The addition of exogenous plasminogen enhanced neurite outgrowth and neurite length in both PC-12 cells and primary cortical neurons. The proteolytic activity of plasmin was required, since mutation of the catalytic serine residue completely abolished the stimulatory activity. Furthermore, mutation of the lysine binding site within kringle 5 of the plasminogen molecule also reduced the neuritogenic activity of plasminogen. Additionally, we demonstrate that plasminogen specifically bound to laminin-1, the interaction resulted in increased plasminogen activation by tissue-type plasminogen activator, and was dependent on a functional lysine binding site within plasminogen kringle 5. Moreover, during NGF-induced neuritogenesis, laminin-1 was degraded, and this cleavage was catalyzed by plasmin. This study provides the first direct evidence that plasminogen participates in neurite outgrowth and also suggests that laminin-1 degradation by plasmin contributes to the process of neuritogenesis.
\end{abstract}

\section{Introduction}

A key feature of the developing nervous system is the growth of neurites along specific pathways. This process requires intracellular signaling, cell migration, interactions with the extracellular matrix (ECM), and proteolytic cleavage of specific substrates. In recent decades, growth factors and growth factor receptors that regulate the development of the nervous system have been identified (Guan and Rao, 2003; Tran and Miller, 2003; Britto et al., 2004). More recently, the molecular components implicated in cell migration and interaction with the ECM have been shown to be key elements in this process (Kiryushko et al., 2004; Pietri et al., 2004). However, the proteolytic enzymes that participate in different steps of axon growth, and the specific substrates they modify, have not been investigated in detail.

The plasminogen (Plg) activation system is composed of a group of serine proteases that play an important role in the remodeling of the ECM during different physiological and pathological processes. Although most studies with this system have

Received July 22, 2009; accepted Aug. 13, 2009.

This work was supported by National Institutes of Health Grants HL045934 and HL081046 (L.A.M.), HL050398 (R.J.P.), and HL013423 (F.J.C.) and by the Department of Veterans Affairs (R.J.P.). We thank Dr. X. S. Puente for helpful revisions and comments and N. Baik for excellent technical assistance. This is publication number 19764 from The Scripps Research Institute.

Correspondence should be addressed to Dr. Lindsey A. Miles, The Scripps Research Institute, 10550 North Torrey Pines Road, La Jolla, CA 92037. E-mail: Imiles@scripps.edu.

DOI:10.1523/JNEUROSCI.3553-09.2009

Copyright $\odot 2009$ Society for Neuroscience ～0270-6474/09/2912393-08\$15.00/0 focused on hepatic-derived Plg, recent reports have demonstrated that Plg and its activator, tissue plasminogen activator (t-PA), are synthesized throughout neuroendocrine tissues (Qian et al., 1993; Sappino et al., 1993; Tsirka et al., 1997; Basham and Seeds, 2001; Zhang et al., 2002). As a result, there is increasing evidence for an important role of the Plg activation system in neuronal development and recovery (Seeds et al., 1999; Akassoglou et al., 2000; Siconolfi and Seeds, 2001a). For example, patients with severe type I Plg deficiency (Plg activity and antigen both extremely low) exhibit symmetric internal hydrocephalus with a Dandy-Walker malformation, hypoplasia of the cerebellum, and a hypoplastic corpus callosum (Schott et al., 1998). Hydrocephalus has also been recognized in Plg-deficient mice (Drew et al., 1998). These syndromes are consistent with defects in neuronal growth and differentiation that are modulated by proteolysis. Proteins of the Plg activation system are induced during axonal outgrowth in murine embryonic dorsal root ganglia (Hayden and Seeds, 1996; Hoover-Plow et al., 2001). Mice lacking Plg or its activators show delayed functional recovery after sciatic nerve crush in the peripheral nervous system (Siconolfi and Seeds, 2001b). Additionally, a series of studies has documented a requirement for Plg activators in neurite outgrowth induced by nerve growth factor (NGF) (Pittman and DiBenedetto, 1995; Farias-Eisner et al., 2001). Furthermore, synthesis of several proteins of the fibrinolytic system, including the urokinase receptor, Plg activator inhibitor-1 and Plg, is regulated by NGF (FariasEisner et al., 2000; Takahashi et al., 2000; Gutierrez-Fernandez et 
al., 2007). Together, these studies strongly support the participation of Plg in neurologic functions.

The importance of the ECM during neuronal development, and the evidence for a role of Plg in neuronal functions, led us to investigate the role of $\mathrm{Plg}$ in neurite outgrowth and determine whether this process was dependent on the interaction of Plg with laminin-1 (LN-1), a major laminin expressed in brain and associated with neuronal growth and development (Lander et al., 1985; Colognato and Yurchenco, 2000). The results of these studies are summarized herein.

\section{Materials and Methods}

Cell culture. Rat pheochromocytoma PC-12 cells, a well established model of NGF-induced neuritogenesis (Greene and Tischler, 1976), were grown in high-glucose DMEM (Invitrogen) containing $2 \mathrm{mM}$ L-glutamine, $100 \mathrm{U} / \mathrm{ml}$ penicillin, and $100 \mu \mathrm{g} / \mathrm{ml}$ streptomycin supplemented with $5 \%$ heat-inactivated calf serum and $10 \%$ heat-inactivated horse serum and maintained in a humidified chamber $\left(37^{\circ} \mathrm{C}, 5 \% \mathrm{CO}_{2}\right)$. Primary rat cortical neurons were provided as microsurgically dissected regions of day 18 embryonic Sprague Dawley rat brain from Genlantis, digested with 20 $\mathrm{U} / \mathrm{mg}$ papain (Sigma), and grown in Neuro culture medium (Neurobasal medium; Invitrogen) supplemented with B27 serum-free supplement and $500 \mu \mathrm{M}$ L-glutamine (Sigma).

For neurite outgrowth experiments, PC-12 cells were grown in serumfree DMEM for $16 \mathrm{~h}$, harvested, washed with serum-free DMEM, and plated on LN-1, the latter of which was coated onto six-well plates in serum-free DMEM. Neurite outgrowth was induced by treatment with $100 \mathrm{ng} / \mathrm{ml} \mathrm{NGF}$ (Invitrogen) in serum-free medium. Culture media, inhibitors, and NGF were replaced daily. For neurite outgrowth in cortical neurons, cells were cultured on poly-L-lysine-coated coverslips in serum-free B27 medium in the presence or absence of $25 \mathrm{~nm} \mathrm{Plg}$, and media were replaced as described above.

Proteins. Human Plg was purified from fresh plasma by affinity chromatography on lysine-Sepharose as described previously (Deutsch and Mertz, 1970) and modified in our laboratory (Miles et al., 1988). Plg mutants $[\mathrm{D}(139) \mathrm{N}] \mathrm{Plg},[\mathrm{D}(218) \mathrm{N}] \mathrm{Plg},[\mathrm{D}(413) \mathrm{N}] \mathrm{Plg},[\mathrm{D}(518) \mathrm{N}] \mathrm{Plg}$, and $[\mathrm{S}(646) \mathrm{E}] \mathrm{Plg}$ were generated by primer-directed mutagenesis and purified from insect conditioned medium as described previously (Menhart et al., 1995). Human plasmin and $\alpha_{2}$-antiplasmin were purchased from American Diagnostica. Monoclonal antibody (mAb) 51 was raised against kringle domains 1-3 of Plg (Pozzi et al., 2000), and $\mathrm{mAb} 2 \mathrm{D} 1$ was raised against mini-Plg (kringle 5 plus protease chain) (Kenagy et al., 1996).

Determination of neurite outgrowth. Cells were plated at low cell densities to minimize neurite contact, and phase-contrast micrographs were captured every $24 \mathrm{~h}$. Images were acquired with a Zeiss Axioplan microscope equipped with a Zeiss $10 \times$ objective and analyzed using the image analysis software Image Pro Plus 4.0 (Media Cybernetics). The percentage of neurite-positive cells was determined by counting the number of cells bearing neurite-like processes greater than the length of the cell soma after treatment and dividing by the total number of cells. A minimum of 150 cells per well in duplicate cultures were counted. For neurite length measurements, data were collected from neurites that did not contact other neurites or cell bodies.

Plg binding assays. Ninety-six well plates (Nalge Nunc International) were coated with LN-1 (Millipore Bioscience Research Reagents) at 1 $\mu \mathrm{g} / \mathrm{ml}$ for $2 \mathrm{~h}$ at $37^{\circ} \mathrm{C}$ in PBS containing $\mathrm{Ca}^{2+}$ and $\mathrm{Mg}^{2+}$. The wells were blocked with $5 \%$ bovine serum albumin (BSA) at $37^{\circ} \mathrm{C}$ for $1 \mathrm{~h}$ and washed three times before incubation with $0.25 \mu \mathrm{M}$ recombinant $\mathrm{Plg}$ (rPlg), plasma Plg, or [D(518)N]Plg for $1 \mathrm{~h}$. The wells were then washed three times with PBS to remove unbound Plg and incubated with primary rabbit anti-human Plg antibody (1:5000 dilution). The wells were rinsed with PBS, incubated with an anti-rabbit antibodyHRP conjugate (1:30,000 dilution; Pierce), washed three times with PBS, and developed using 1,2-phenylene diamine-dihydrochloride (Dako). Color development was measured at $450 \mathrm{~nm}$ in a microtiter plate reader (Molecular Devices). Each experiment was performed in triplicate.

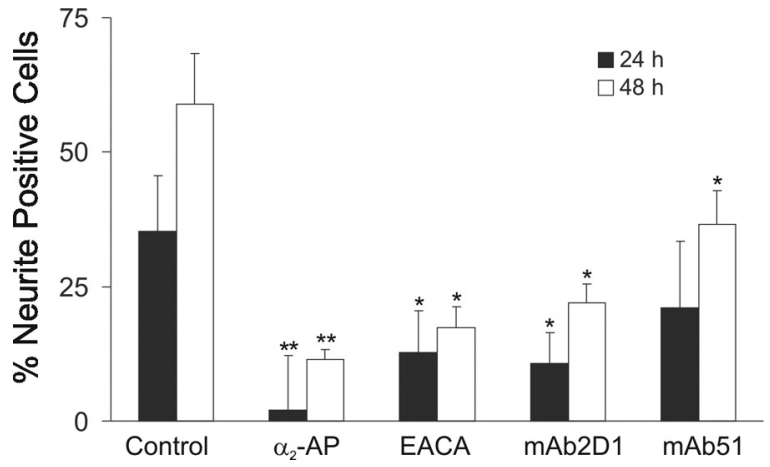

Figure 1. Plasmin participates in NGF-induced neuritogenesis. $P C-12$ cells were cultured in serum-free medium on LN-1-coated plates for $12 \mathrm{~h}$ and stimulated with NGF in the absence or presence of $\alpha_{2}$-antiplasmin ( $\alpha_{2}$-AP; $25 \mathrm{~nm}$ ), EACA (100 mM), mAb51, mAb 2D1, or isotype control (40 $\mu \mathrm{g} / \mathrm{ml}$ ), and neurite-positive cells were determined after $24 \mathrm{~h}$ (filled bars) or $48 \mathrm{~h}$ (open bars) as described in Materials and Methods. Data represent the mean of three independent experiments \pm SEM $\left({ }^{*} p<0.05 ;{ }^{* *} p<0.01\right)$.

Plg activation. Purified LN-1 or BSA was coated onto 96-well plates at $1 \mu \mathrm{g} / \mathrm{ml}$ as above, and wells were blocked with $5 \%$ BSA and washed three times with $20 \mathrm{~mm}$ HEPES, $\mathrm{pH}$ 7.4. Plg was added at a final concentration of $0.3 \mu \mathrm{M}$ and incubated at $37^{\circ} \mathrm{C}$ for $1 \mathrm{~h}$, followed by the addition of 0.3 $\mathrm{mm}$ of the plasmin substrate VLK-pNA (Val-Leu-Lys- p-nitroanilide) (Sigma). Activation of Plg was initiated by the addition of $0.55 \mathrm{~nm}$ t-PA (American Diagnostica). Hydrolysis of VLK-pNA by plasmin was measured as the change in absorbance at $405 \mathrm{~nm}$ over time using a microplate reader. Plg activation was determined as the increment in $V_{\mathrm{o}}$ (mol of $\mathrm{Pm} / \mathrm{min})$ using the following equation: $V_{\mathrm{o}}=b(1+\mathrm{Km} / \mathrm{So}) / \varepsilon \mathrm{kcat}$.

Western blotting. Proteins were subjected to SDS-PAGE on $8 \%$ gels under reducing conditions, transferred to nitrocellulose (GE Healthcare), and incubated with a rabbit polyclonal antibody against murine LN-1 (Sigma). The membrane was incubated with an anti-rabbit antibody-HRP conjugate, developed using an ECL substrate (Pierce), and subjected to autoradiography using Kodak Biomax MR Film (Thermo Fisher Scientific).

Statistics. Data are presented as means \pm SEM. Results were analyzed by ANOVA followed by Student-Newman-Keuls post hoc tests for multiple comparisons.

\section{Results}

\section{Plasminogen enhances neurite outgrowth in PC-12 cells and} primary cortical neurons

A series of studies has supported a requirement for an intact $\mathrm{Plg}$ activation system in neurite outgrowth induced by NGF (Pittman and DiBenedetto, 1995; Farias-Eisner et al., 2001; Jacovina et al., 2001). We have recently shown that Plg gene expression is induced by NGF in PC-12 cells (Gutierrez-Fernandez et al., 2007). Therefore, we examined the role of plasmin in NGF-dependent neurite outgrowth. PC-12 cells were grown on LN-1 and treated with NGF in the presence or absence of the plasmin inhibitor $\alpha_{2}$-antiplasmin, an anticatalytic mAb against the serine protease domain of Plg (mAb 2D1) (Kenagy et al., 1996); $\varepsilon$-aminocaproic acid (EACA), which blocks the interaction of Plg with cells (Miles et al., 2005); or mAb51, an anti-Plg antibody that inhibits binding of Plg to cellular receptors (Pozzi et al., 2000; Tarui et al., 2001). The effects of these reagents on neuritogenesis and neurite outgrowth were evaluated (Fig. 1). Treatment with either $\alpha_{2}$ antiplasmin or mAb $2 \mathrm{D} 1$ resulted in a significant reduction of neurite-positive cells (90 and 78\%, respectively, after $48 \mathrm{~h}$ of treatment) compared with control cells treated with an isotype control (Fig. 1). Neurite length was also reduced by these inhibitors (data not shown). These data support a requirement for plasmin activity for optimal neurite outgrowth. These data also 
suggest that Plg is synthesized by the cells and activated to plasmin, consistent with the synthesis of Plg and t-PA by the adrenal gland and by PC-12 cells (Kristensen et al., 1986; Parmer et al., 1997; Zhang et al., 2002; Gutierrez-Fernandez et al., 2007). In addition, treatment with reagents that inhibit binding of $\mathrm{Plg} /$ plasmin to cells, including mAb51 or EACA, also reduced NGFinduced neuritogenesis by 38 and 71\%, respectively, consistent with a requirement for the interaction of plasmin with the cell surface and/or the ECM. [The percentage of inhibition by MAb51 is consistent with its effect in our previous publication (Pozzi et al., 1998).] Similar results were obtained with rat primary cortical neurons in which EACA treatment reduced the percentage of neurite-positive cells from $62+2 \%$ to $28+7 \%$.

To further explore the role of Plg/plasmin in neurite outgrowth, we examined the effect of the addition of exogenous Plg on neurite outgrowth in both PC-12 cells and primary rat cortical cells. [We have previously compared Plg mRNA levels in murine liver and adrenal gland and found that, although adrenal has the highest level of extrahepatic Plg mRNA, this level is only $1.3 \%$ of the level of hepatic mRNA and Plg mRNA levels in brain are $0.03 \%$ of hepatic levels (Zhang et al., 2002). Thus, we have not been able to detect Plg by ELISA in these cells and so cannot directly compare the levels of exogenous and endogenous Plg. By extrapolation, we added exogenous Plg at $25 \mathrm{~nm}$ (12.5\% of the plasma Plg concentration) (Collen and Verstraete, 1975), so the ratio of exogenous Plg to endogenous Plg is in the range of 10:1.]

PC- 12 cells were plated on wells coated with LN-1, cultured in either the presence or absence of $25 \mathrm{nM} \mathrm{Plg}$, and examined for neurite outgrowth, induced by the addition of NGF. Plg enhanced neurite outgrowth, resulting in a twofold increase in neurite-positive cells (Fig. 2A) and neurite length (Fig. $2 B$ ). In the absence of NGF, Plg did not stimulate neurite outgrowth (data not shown). Plg treatment also enhanced neuritogenesis of primary rat cortical neurons. The percentage of neurite-positive cells (Fig. 2C,E) and neurite length (Fig. 2D,E) were increased 1.8-fold and 2.1-fold, respectively, by the addition of Plg. Together, these results suggest that Plg/plasmin enhances neurite outgrowth and the proteolytic activity of plasmin is required for this process.

\section{Structural requirements for Plg-dependent enhancement of neurite outgrowth}

The lysine analog EACA blocks the interactions of Plg with macromolecular cofactors and inhibitors, as well as cell-surface receptors, by interacting with lysine binding sites contained within the kringle structures of Plg (Menhart et al., 1995; Castellino and McCance, 1997; Miles et al., 2005). Therefore, the specific Plg kringles participating in the enhancement in NGF-dependent neurite outgrowth were examined. Plg variants, in which the lysine binding function of kringles 1, 2, 4, and 5 were inactivated individually, were studied: $[\mathrm{D}(139) \mathrm{N}] \mathrm{Plg},[\mathrm{D}(218) \mathrm{N}] \mathrm{Plg}$, $[\mathrm{D}(413) \mathrm{N}] \mathrm{Plg}$, and $[\mathrm{D}(518) \mathrm{N}] \mathrm{Plg}$ (McCance and Castellino, 1995; Menhart et al., 1995). [Kringle 3 does not exhibit significant lysine binding ability (Menhart et al., 1995).] Each of these Plg mutants, wild-type rPlg, or buffer was added, separately, to PC-12 cells grown on LN-1 in the presence of NGF. After 48 h, neurite outgrowth was compared with that observed in the presence of plasma-derived Plg (Fig. 3). Similar to the results in Fig. 2, the number of neurite-positive cells was increased in the presence of either plasma-derived Plg (1.8-fold) or rPlg (1.7-fold) compared with cells treated with NGF without the addition of Plg (Fig. $3 A, B)$. The addition of either the Plg mutants, $[\mathrm{D}(139) \mathrm{N}] \mathrm{Plg}$, $[\mathrm{D}(218) \mathrm{N}] \mathrm{Plg}$, or $[\mathrm{D}(413) \mathrm{N}] \mathrm{Plg}$ resulted in an increase in the
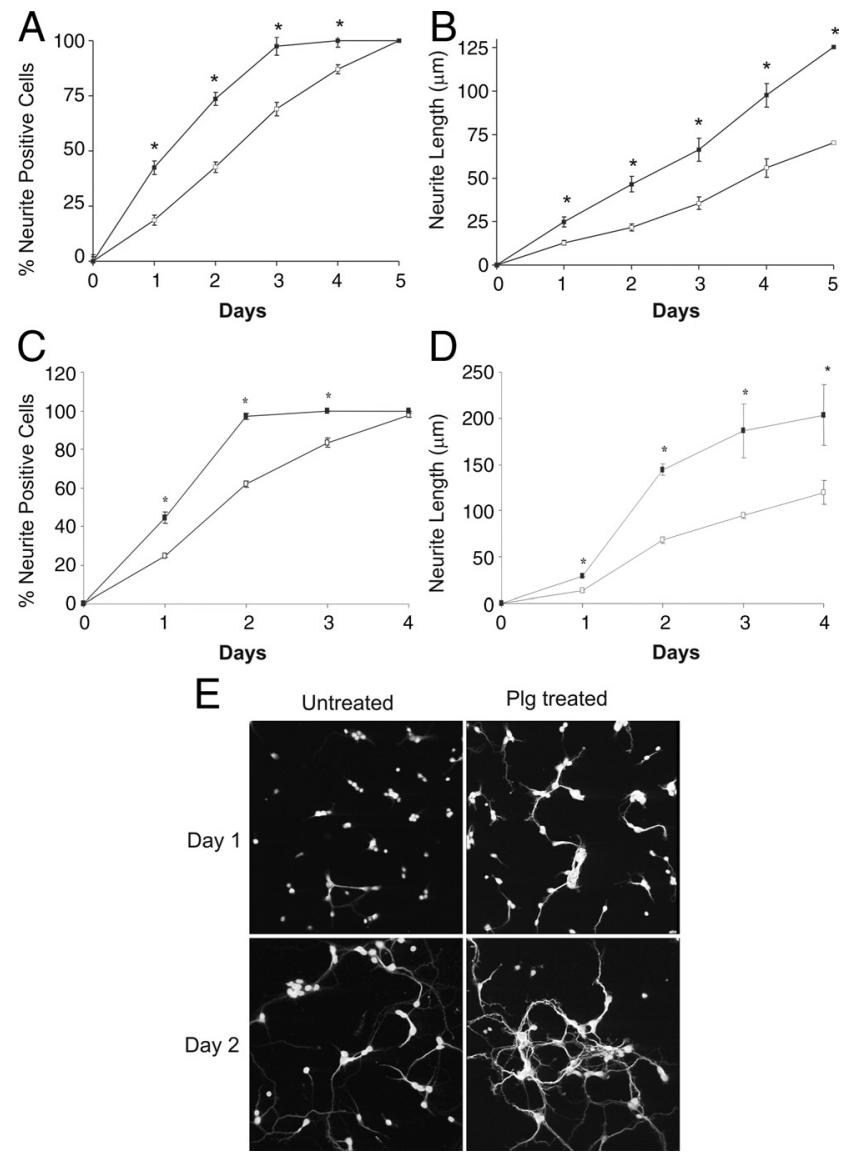

Figure 2. Plg enhances neurite outgrowth. $A, B, P C-12$ cells were cultured in serum-free medium on LN-1-coated plates for $12 \mathrm{~h}$ before stimulation with NGF. $\boldsymbol{C}-\boldsymbol{E}$, Cortical cells were cultured on poly-L-lysine-coated coverslips in serum-free B27 medium in the presence $(\square)$ or absence $(\square)$ of $\mathrm{Plg}(25 \mathrm{~nm})$. Neurite-positive cells $(\boldsymbol{A}, \boldsymbol{C})$ were counted as described in Materials and Methods, and neurite length $(\boldsymbol{B}, \boldsymbol{D})$ was measured every $24 \mathrm{~h}$ for the duration of the experiment from neurites that did not contact other neurites or other cell bodies. $\boldsymbol{E}$, Representative phase-contrast micrographs of cortical cells incubated with $\mathrm{Plg}(25 \mathrm{~nm})$. Images were taken using an inverted microscope at $40 \times$ magnification. All statistical analyses were performed using the one-way ANOVA ( ${ }^{*} p<0.05$ ). Data represent the mean of three independent experiments \pm SEM.

number of neurite-positive cells similar to that observed with rPlg (Fig. $3 A, B$ ), suggesting that a functional lysine binding site in either kringle 1, 2, or 4 is not required for enhancement of neurite outgrowth. In contrast, the Plg mutant $([\mathrm{D}(518) \mathrm{N}] \mathrm{Plg}) \mathrm{ex}-$ hibited only $15 \%$ of the effect of $\mathrm{rPlg}$ on the percentage of neuritepositive cells. Similarly, when the cells were treated with NGF plus the mutants $[\mathrm{D}(139) \mathrm{N}] \mathrm{Plg},[\mathrm{D}(218) \mathrm{N}] \mathrm{Plg}$, or $[\mathrm{D}(413) \mathrm{N}] \mathrm{Plg}$, neurite length was increased and was not significantly different than in the presence of rPlg (Fig. $3 A, C$ ). However, in the presence of $[\mathrm{D}(518) \mathrm{N}] \mathrm{Plg}$, neurite length was increased by only $17 \%$ compared with $\mathrm{rPlg}$ (Fig. $3 A, C$ ). These data support a requirement for the lysine binding site within Plg kringle 5 in the ability of Plg to enhance neurite outgrowth.

The data of Fig. 1, in which anticatalytic anti-Plg mAb 2D1 blocked neurite outgrowth in response to NGF, led to further investigation of the requirement for the plasmin active site in neurite outgrowth. Accordingly, we used a Plg variant in which the Asp residue of the catalytic triad of the serine protease domain was replaced by a Glu residue to generate [D(646)E]Plg. This variant can be cleaved by Plg activators to the two-chain plasmin form but does not exhibit detectable proteolytic activity (Grella 
A
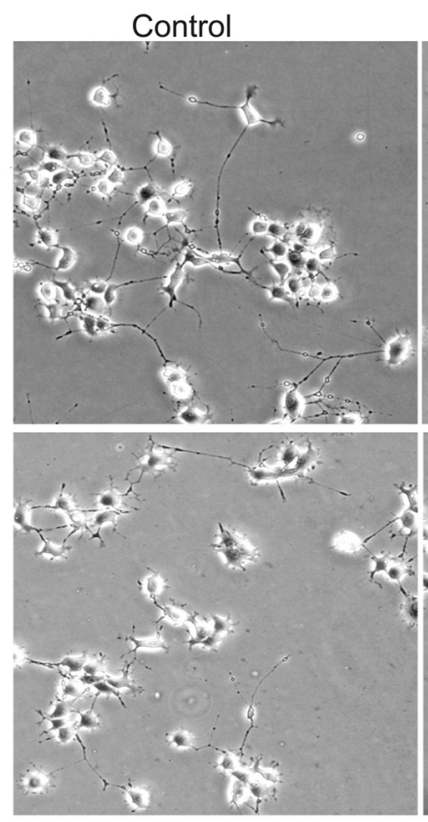

$\mathrm{D}[(518) \mathrm{N}] \mathrm{Plg}$
$\mathrm{D}[(139) \mathrm{N}] \mathrm{Plg}$
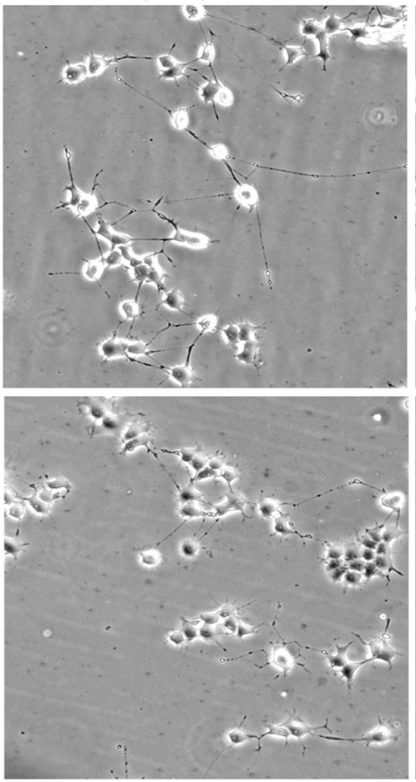

$\mathrm{D}[(646) \mathrm{E}] \mathrm{Plg}$
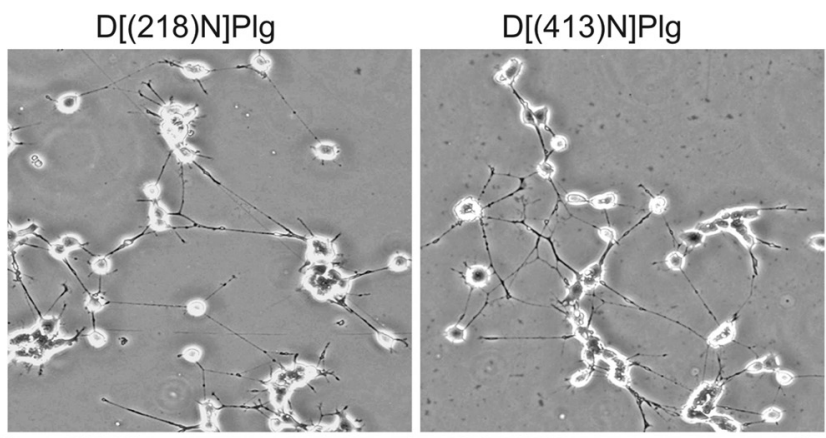

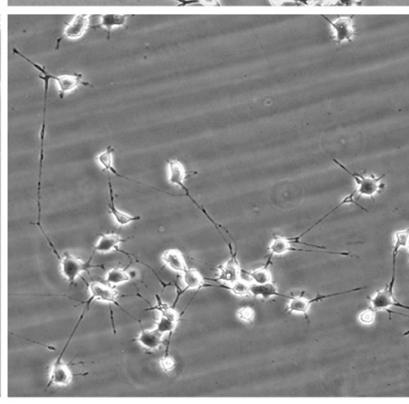

rPlg

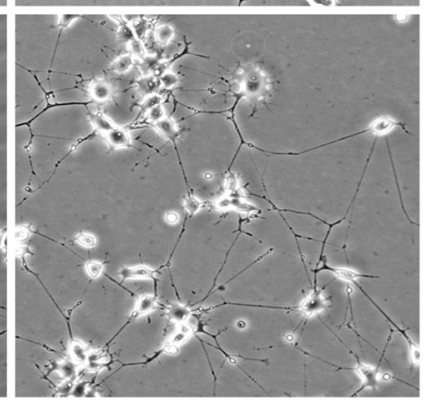

Plg
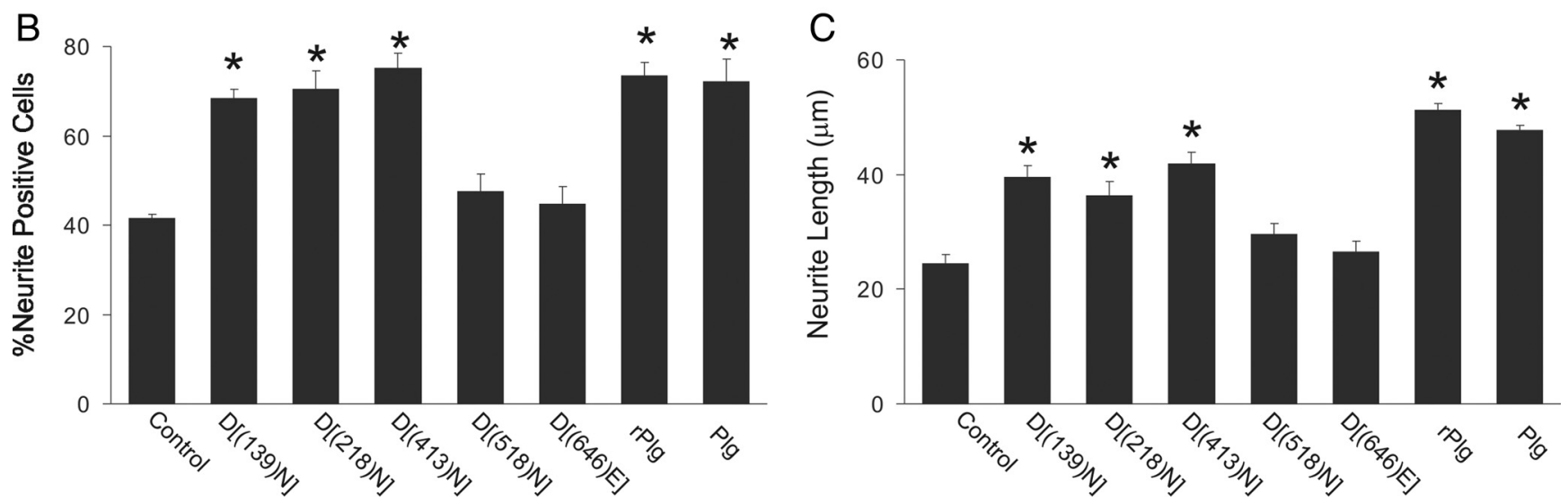

Figure 3. Identification of Plg domains responsible for neurite outgrowth. A, Representative phase-contrast micrographs of NGF-treated PC- 12 cells stimulated with $25 \mathrm{~nm}$ of the indicated Plg variants. Images were taken using an inverted microscope at $10 \times$ magnification. $\boldsymbol{B}, \boldsymbol{C}$, The percentage of neurite-positive cells $(\boldsymbol{B})$ and the average length of NGF-stimulated cells $(\boldsymbol{C})$ in the presence of each Plg variant were determined after $48 \mathrm{~h}$ of treatment as described in Materials and Methods. Data represent the mean of three independent experiments \pm SEM ( $\left.{ }^{*} p<0.05\right)$ compared with cells incubated without PIg.

and Castellino, 1997). When PC-12 cells were grown on LN-1 and stimulated with NGF in the presence of [D(646)E]Plg, the percentage of neurite-positive cells and neurite length were not significantly increased compared with cells grown in medium alone. These results suggest that the proteolytic activity of plasmin is required for enhancement of neurite outgrowth by $\mathrm{Plg}$, consistent with activation by $\mathrm{PC}$-12-derived t-PA (Parmer et al., 1997).

\section{LN-1 is proteolytically cleaved by plasmin}

The ability of plasmin to cleave laminins within the ECM (Chen and Strickland, 1997; Indyk et al., 2003) prompted us to investigate whether LN-1 degradation occurred during NGF-induced neurite outgrowth and whether this cleavage was plasmin dependent. PC-12 cells were grown on LN-1 and either untreated or treated with $100 \mathrm{ng} / \mathrm{ml} \mathrm{NGF}$ in the presence or absence of $\alpha_{2}$ antiplasmin or t-PA. To investigate the status of LN-1, the cells were detached, and the ECM was harvested, subjected to electrophoresis and Western blotting with polyclonal anti-murine LN-1. LN-1 degradation was observed in ECM harvested from cells treated with NGF, as shown by the decreased intensity of both the $\alpha 1$ chain (migrating with a $\mathrm{M}_{\text {rapp }}$ of $440 \mathrm{kDa}$ ) and the $\beta 1 \gamma 1$ chain (migrating with a $\mathrm{M}_{\text {rapp }}$ of $220 \mathrm{kDa}$ ) compared with ECM harvested from cells cultured in the absence of NGF (Fig. $4 A$ ). In addition, $\mathrm{LN}-1$ proteolytic fragments in the $\mathrm{M}_{\text {rapp }}$ range of $48-140 \mathrm{kDa}$ were detected in the culture medium of NGFtreated cells, but not untreated cells (Fig. 4B). Furthermore, the NGF-dependent LN-1 degradation was consistent with a plasmin-dependent mechanism because $\alpha_{2}$-antiplasmin reduced the extent of degradation by $68 \%$, compared with ECM harvested from cells treated with NGF alone (Fig. $4 A$ ), and also reduced the presence of LN-1 degradation fragments in the conditioned medium (Fig. $4 B$ ). The addition of t-PA resulted in enhanced degradation of $\mathrm{LN}-1$ by $160 \%$ compared with the ECM harvested from cells treated with NGF alone (Fig. 4A) and also increased the intensity of LN-1 degradation fragments in the conditioned medium (Fig. 4B), consistent with a role for cellular plasmin in degradation of LN-1. These data suggest that LN-1 degradation is increased during NGF-induced neuritogenesis and that the degradation is plasmin dependent. 
A
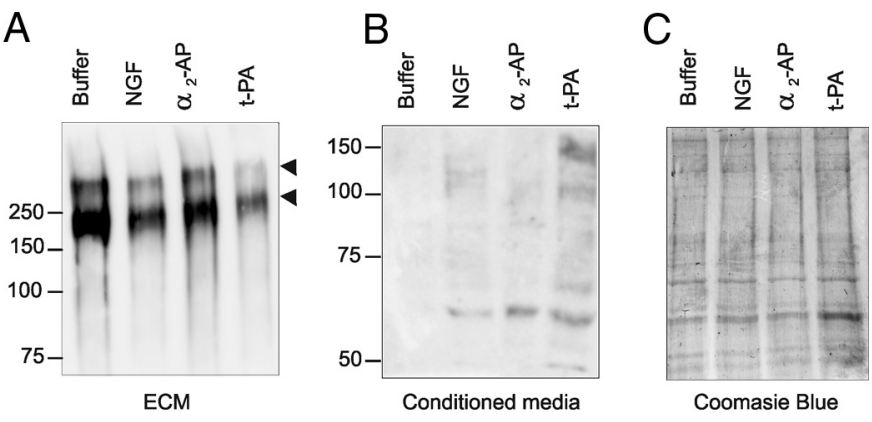

Figure 4. LN-1 is cleaved during neuritogenesis. PC-12 cells $\left(1 \times 10^{6}\right)$ were plated on 24-well plates coated with LN-1 (1 $\mu \mathrm{g} / \mathrm{ml}$ ) in serum-free medium in the absence (buffer) or presence of $100 \mathrm{ng} / \mathrm{ml} \mathrm{NGF}$ and in the absence or presence of either $\alpha_{2}$-antiplasmin $\left(\alpha_{2}-\mathrm{AP} ; 25 \mathrm{~nm}\right)$ or t-PA $(10 \mathrm{~nm})$, and cultured for $20 \mathrm{~h}$ at $37^{\circ} \mathrm{C}$. Conditioned media $(\boldsymbol{B})$ was harvested, and the ECM $(A, C$ was collected after detaching the cells by incubation with $5 \mathrm{~mm}$ EDTA. Samples were subjected to Western blotting using a polyclonal antibody against $\mathrm{LN}-1(\boldsymbol{A}, \boldsymbol{B})$ or stained with Coomassie Blue as a loading control (C). Arrowheads denote the $\alpha 1$ chain (migrating with a $\mathrm{M}_{\text {rapp }}$ of $440 \mathrm{kDa}$ ) and the $\beta 1 \gamma 1$ chain (migrating with a $\mathrm{M}_{\text {rapp }}$ of $220 \mathrm{kDa}$ ) of $\mathrm{LN}-1$. The relative intensities of the two major chains of LN-1 were determined relative to the Coomassie Blue-stained gel and normalized to the results of cells treated with buffer alone. Representative gels of experiments performed at least three times each are shown.

\section{Plg binding to $\mathrm{LN}-1$ enhances activation by t-PA}

A characteristic feature of plasmin substrates, including fibrin and laminin-5, is their ability to interact with Plg and promote its activation by Plg (Goldfinger et al., 2000; Waisman, 2003). Whether Plg could also bind LN-1 and facilitate its activation to plasmin was tested. Microtiter plates coated with LN-1 or BSA were incubated in the presence or absence of rPlg or plasma Plg, and bound protein was detected by ELISA using a mAb against human Plg. Plg binding to LN-1 was detected, whereas no significant binding to BSA was observed (Fig. 5A). Furthermore, this interaction was specific because it was inhibited by $66 \pm 7 \%(n=$ 3 ) in the presence of $100 \mathrm{~mm}$ EACA. This suggests that the interaction of Plg with $\mathrm{LN}-1$ requires an interaction with the lysine binding sites in Plg. In contrast, the ability of [D(518)N]Plg to bind to LN-1 was decreased by $70 \%$ compared with rPlg or plasma Plg, suggesting that an intact lysine binding site in the kringle 5 domain of Plg is required for binding to LN-1 (Fig. 5A), as well as for stimulation of neuritogenesis (Fig. 3).

To determine whether Plg binding to LN-1 enhanced its activation by t-PA, microtiter plates coated with either LN-1 or BSA were incubated with rPlg or plasma for 30 min to allow binding, and then t-PA was added. The activation rate of rPlg or plasma Plg bound to LN-1 was fourfold greater than the activation rate of soluble Plg (incubated with plates coated with BSA; data not shown). In contrast, the activation rate of [D(518)N]Plg bound to $\mathrm{LN}-1$ was only $50 \%$ of the activation rates of $\mathrm{rPlg}$ and plasma Plg (Fig. 5B). These results demonstrate that Plg binding to LN enhances its activation and that a functional kringle 5 domain within the Plg molecule is required for the enhanced activation. No significant differences where observed in the activation rates of soluble rPlg, plasma Plg, and soluble [D(518)N]Plg. Together, these results suggest that the neurite outgrowth promoting capacity of Plg is dependent on its direct effect on laminin degradation.

\section{Plg binding to $\mathrm{LN}-1$ enhances neuritogenesis}

The above data suggested that plasmin activity was required for neurite outgrowth and that the interaction of Plg with LN-1 promoted Plg activation. Therefore, to examine whether Plg binding to $\mathrm{LN}-1$ could influence NGF-induced neurite outgrowth, LN-1-coated plates were either preincubated with $25 \mathrm{~nm}$ Plg (Fig. 6, open bars) or buffer (Fig. 6, filled bars) for $1 \mathrm{~h}$ to allow binding of Plg to LN-1 before the addition of the cells. Next, PC-12 cells were added simultaneously with soluble $\mathrm{Plg}(+)$ or $\operatorname{buffer}(-)$, at the initiation of culture. NGF was added to the culture medium, and neurite outgrowth was quantified at $16 \mathrm{~h}$ after plating. Pretreatment of LN-1 with Plg enhanced both the percentage of neuritepositive cells and neurite length compared with cells that had been exposed to Plg at the initiation of the cultures (Fig. 6, compare open and filled bars).

\section{Discussion}

The importance of proteolysis in the nervous system has been demonstrated by the identification of numerous neurological diseases caused by alterations in the activity of specific proteases, including neurotrypsin in mental retardation; UCHL-1 in Parkinson's disease; and $\alpha-, \beta$-, and $\gamma$-secretases in Alzheimer's disease (Esler and Wolfe, 2001; Liu et al., 2002; Molinari et al., 2002; Vassar, 2002). However, the physiological role for most proteases expressed in the nervous system remains primarily unknown. A series of previous studies has documented a requirement for Plg activators in neurite outgrowth induced by NGF (Pittman and DiBenedetto, 1995; Farias-Eisner et al., 2001). In the current study, we investigated the function of plasmin in these processes. We found that (1) Plg enhanced neurite outgrowth and neuritogenesis; (2) the proteolytic activity of plasmin and the lysine binding sites in the kringle 5 domain of Plg were necessary for the enhancement; (3) LN-1 was cleaved during neurite outgrowth; and (4) Plg bound to LN-1, resulting in increased $\mathrm{Plg}$ activation and the enhancement of neurite outgrowth and neuritogenesis. As a whole, these data suggest a major mechanism by which proteolysis of a major component of the neuronal ECM promotes neurite outgrowth and neuritogenesis.

Although the fibrinolytic system has been classically associated with vascular processes, recent reports have shown that some of its proteins participate in neurological functions (Hayden and Seeds, 1996; Drew et al., 1998; Schott et al., 1998; Seeds et al., 1999; Akassoglou et al., 2000; Hoover-Plow et al., 2001; Siconolfi and Seeds, 2001b). The presence of the hematoencephalic barrier prevents the diffusion of hepatic-derived Plg into neural tissues. However, recent reports have demonstrated that proteins of the fibrinolytic system (i.e., Plg and t-PA) are broadly expressed throughout the neuroendocrine system (Kristensen et al., 1986; Parmer et al., 1997; Zhang et al., 2002; Gutierrez-Fernandez et al., 2003). In fact, our studies have shown that NGF upregulates the expression of the Plg gene (Gutierrez-Fernandez et al., 2007). In the current study, we found that blockade of the proteolytic activity of plasmin delayed NGF-dependent neuritogenesis and neurite outgrowth.

These data are consistent with a requirement for cellular Plg during neuritogenesis and suggest that $\mathrm{Plg}$, activated by t-PA, is necessary for this process. We suggest that the direct participation of Plg in neuritogenesis contributes to the neurological abnormalities associated with defects in this protein. In this regard, it 

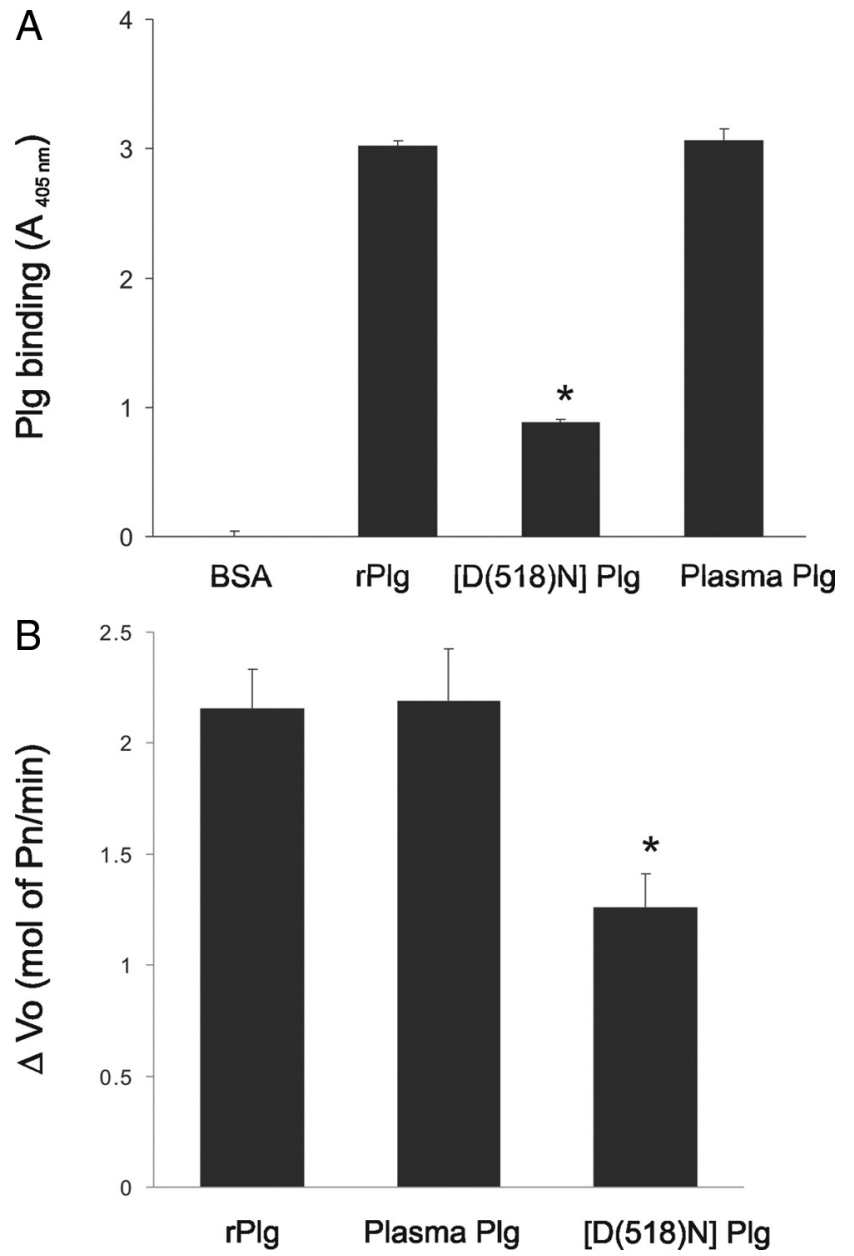

Figure 5. Plasminogen binding to LN-1 enhances its activation by t-PA. $\boldsymbol{A}$, Ninety-sixwell plates coated with LN-1 or BSA were incubated with rPlg, plasma Plg, or [D(518) N]Plg for $1 \mathrm{~h}$ at $37^{\circ} \mathrm{C}$, and bound Plg was detected by ELISA as described in Materials and Methods. $\boldsymbol{B}$, The effect of Plg binding to LN-1 on Plg activation was tested as described in Materials and Methods. Plg activation by t-PA when bound to LN-1 was determined as hydrolysis of the chromogenic substrate VLK-pNA after the addition of t-PA and expressed as the increase in $V_{0}(\mathrm{~mol}$ of $\mathrm{Pm} / \mathrm{min}$ ) compared with the rate of activation of soluble plasminogen in plates coated with BSA. Data shown are the mean of three independent experiments \pm SEM $\left({ }^{*} p<0.05\right)$.

has been shown that patients with severe type I Plg deficiency exhibit neuropathologies (Schott et al., 1998). These syndromes are consistent with defects in neuronal growth and differentiation that are modulated by proteolysis, and these data support a major role for proteins of the fibrinolytic system in neuritogenesis.

The activity of Plg during neuritogenesis not only depends on its proteolytic activity but also requires additional interactions with proteins. In fact, as shown here, the lysine-binding properties of Plg are necessary for neuritogenic activity.

We found that binding of Plg to LN-1 enhanced Plg activation and neurite outgrowth, and this binding, enhancement of Plg activation, and enhancement of neurite outgrowth were dependent on a functional kringle 5 domain. Furthermore, LN-1 was found to be a plasmin substrate that was cleaved during NGFinduced neurite outgrowth. Furthermore, inhibition of plasmin activity inhibited neurite outgrowth as well as LN-1 degradation. Our results indicate that LN-1 is a plasmin substrate and also suggest that $\mathrm{LN}-1$ degradation by plasmin is a major mechanism facilitating neurite outgrowth. Our studies suggest that binding
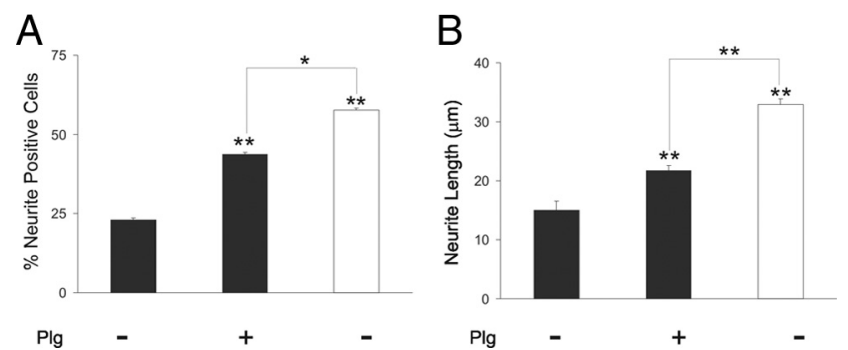

Figure 6. Neurite outgrowth enhancement by plasminogen binding to LN-1. LN-1coated plates were preincubated in the presence of Plg $25 \mathrm{~nm}$ (open bars) or buffer (filled bars) at $37^{\circ} \mathrm{C}$ for $1 \mathrm{~h}$ before the addition of the cells. Then $\mathrm{PC}-12$ cells were added simultaneously at the initiation of the culture with soluble $\mathrm{Plg}(+)$ or buffer $(-)$. NGF was then added, and percentage of neurite-positive cells and neurite length were quantified at $16 \mathrm{~h}$. Neurite-positive cells $(\boldsymbol{A})$ and neurite length $(\boldsymbol{B})$ were quantified as described in Materials and Methods. Data shown are the mean of three independent experiments \pm SEM $\left({ }^{*} p<0.05 ;{ }^{* *} p<0.01\right)$.

to LN-1 may provide a general mechanism to achieve Plg activation in neuronal tissues, similar to the activation of fibrin-bound Plg during fibrinolysis. This interaction would not only contribute to the spatial localization of Plg, but plasmin generated at the cell surface would be available to cleave LN-1 or other ECM substrates, thus facilitating neurite outgrowth. Thus, during neural development and neuritogenesis, plasmin activity is likely to be required to cleave LN-1 and may activate other proteinases, facilitating migration and perhaps promoting different signaling events by exposing cryptic sites or liberating proteolytic fragments with biological activity. Cleavage of LN-5 by MMP-2 has been shown to expose a cryptic site that induces migration of epithelial cells (Giannelli et al., 1997), demonstrating that processing of laminins by specific proteases may contribute to processes requiring cell migration. Interestingly, although LN-1 $(\alpha 1 \beta 1 \gamma 1)$ is one of the major laminins in neural tissues, other components of this family, including LN-2 ( $\alpha 2 \beta 1 \gamma 1)$ and LN-10 $(\alpha 5 \beta 1 \gamma 1)$, are also expressed in neural tissues and have been associated with neurite outgrowth (Vuolteenaho et al., 1994; Powell et al., 1998; Colognato and Yurchenco, 2000; Fried et al., 2005), suggesting that cleavage of these proteins by plasmin could also contribute to neuritogenesis.

The results presented here suggest that the Plg activation system upregulates neuritogenesis. Consistent with our findings, several studies have shown that Plg and t-PA protect against axonal degeneration after sciatic nerve injury in the peripheral nervous system by cleaving fibrin (Akassoglou et al., 2000). However, the role of the fibrinolytic system in degradation of LN-1 in nervous tissue may be multifaceted. Plasmin-catalyzed degradation of LN-1 or LN-10 in the hippocampus mediates excitotoxic-induced neuronal cell anoikis attributable to loss of cell attachment (Chen and Strickland, 1997; Indyk et al., 2003). Excitotoxic glutamate agonists stimulate synthesis of Plg that is then activated to plasmin, contributing to neuronal cell death (Chen and Strickland, 1997). Thus, Plg expression and activation within neuronal tissues must be strictly regulated because failure to control this balance can have pathologic consequences.

In summary, our studies suggest that proteolysis by plasmin regulates neurite outgrowth by cleavage of LN-1. The interaction of this protease with LN-1 may represent a general mechanism by which neuronal Plg can be efficiently activated to facilitate ECM remodeling and neurite outgrowth, suggesting a previously unrecognized role of the fibrinolytic system in neurological functions. 


\section{References}

Akassoglou K, Kombrinck KW, Degen JL, Strickland S (2000) Tissue plasminogen activator-mediated fibrinolysis protects against axonal degeneration and demyelination after sciatic nerve injury. J Cell Biol 149:1157-1166.

Basham ME, Seeds NW (2001) Plasminogen expression in the neonatal and adult mouse brain. J Neurochem 77:318-325.

Britto JM, Lukehurst S, Weller R, Fraser C, Qiu Y, Hertzog P, Busfield SJ (2004) Generation and characterization of neuregulin-2-deficient mice. Mol Cell Biol 24:8221-8226.

Castellino FJ, McCance SG (1997) The kringle domains of human plasminogen. Ciba Found Symp 212:46-60.

Chen LW, Strickland S (1997) Neuronal death in the hippocampus is promoted byplasmin-catalyzed degradation of laminin. Cell 91:917-925.

Collen D, Verstraete M (1975) Molecular biology of human plasminogen. II. Metabolism in physiological and some pathophysiological conditions in man. Thromb Diath Haemorrh Suppl 34:403-408.

Colognato H, Yurchenco PD (2000) Form and function: the laminin family of heterotrimers. Dev Dyn 218:213-234.

Deutsch DG, Mertz ET (1970) Plasminogen: purification from human plasma by affinity chromatography. Science 170:1995-1996.

Drew AF, Kaufman AH, Kombrinck KW, Danton MJS, Daugherty CC, Degen JL, Bugge TH (1998) Ligneous conjunctivitis in plasminogen-deficient mice. Blood 91:1616-1624.

Esler WP, Wolfe MS (2001) A portrait of Alzheimer secretases-new features and familiar faces. Science 293:1449-1454.

Farias-Eisner R, Vician L, Silver A, Reddy S, Rabbani SA, Herschman HR (2000) The urokinase plasminogen activator receptor (UPAR) is preferentially induced by nerve growth factor in PC12 pheochromocytoma cells and is required for NGF-driven differentiation. J Neurosci 20:230-239.

Farias-Eisner R, Vician L, Reddy S, Basconcillo R, Rabbani SA, Wu YY, Bradshaw RA, Herschman HR (2001) Expression of the urokinase plasminogen activator receptor is transiently required during "priming" of PC12 cells in nerve growth factor-directed cellular differentiation. J Neurosci Res 63:341-346.

Fried K, Sime W, Lillesaar C, Virtanen I, Tryggvasson K, Patarroyo M (2005) Laminins 2 (alpha2betalgammal, Lm-211) and 8 (alpha4betalgammal, $\mathrm{Lm}-411$ ) are synthesized and secreted by tooth pulp fibroblasts and differentially promote neurite outgrowth from trigeminal ganglion sensory neurons. Exp Cell Res 307:329-341.

Giannelli G, Falk-Marzillier J, Schiraldi O, Stetler-Stevenson WG, Quaranta V (1997) Induction of cell migration by matrix metalloprotease-2 cleavage of laminin-5. Science 277:225-228.

Goldfinger LE, Jiang L, Hopkinson SB, Stack MS, Jones JC (2000) Spatial regulation and activity modulation of plasmin by high affinity binding to the $\mathrm{G}$ domain of the alpha 3 subunit of laminin-5. J Biol Chem 275:34887-34893.

Greene LA, Tischler AS (1976) Establishment of a noradrenergic clonal cell line of rat adrenal pheochromocytoma cells which respond to nerve growth factor. Proc Natl Acad Sci U S A 73:2424-2428.

Grella DK, Castellino FJ (1997) Activation of human plasminogen by staphylokinase. Direct evidence that preformed plasmin is necessary for activation to occur. Blood 89:1585-1589.

Guan KL, Rao Y (2003) Signalling mechanisms mediating neuronal responses to guidance cues. Nat Rev Neurosci 4:941-956.

Gutierrez-Fernandez A, Gingles NA, Zhang L, Garcia Bannach F, Jenkins GR, Loskutoff DJ, Parmer RJ, Miles LA (2003) Regulation of plasminogen gene expression. In: Plasminogen regulation (Waisman DM, ed), pp 6780. New York: Academic/Plenum Publishers.

Gutierrez-Fernandez A, Parmer RJ, Miles LA (2007) Plasminogen gene expression is regulated by nerve growth factor. J Thromb Haemost 5:1715-1725.

Hayden SM, Seeds NW (1996) Modulated expression of plasminogen activator system components in cultured cells from dissociated mouse dorsal root ganglia. J Neurosci 16:2307-2317.

Hoover-Plow J, Skomorovska-Prokvolit O, Welsh S (2001b) Selective behaviors altered in plasminogen-deficient mice are reconstituted with intracerebroventricular injection of plasminogen. Brain Res 898:256-264.

Indyk JA, Chen ZL, Tsirka SE, Strickland S (2003) Laminin chain expression suggests that laminin-10 is a major isoform in the mouse hippocampus and is degraded by the tissue plasminogen activator/plasmin protease cascade during excitotoxic injury. Neuroscience 116:359-371.
Jacovina AT, Zhong F, Khazanova E, Lev E, Deora AB, Hajjar KA (2001) Neuritogenesis and the nerve growth factor-induced differentiation of PC-12 cells requires annexin II-mediated plasmin generation. J Biol Chem 276:49350-49358.

Kenagy RD, Vergel S, Mattsson E, Bendeck M, Reidy MA, Clowes AW (1996) The role of plasminogen, plasminogen activators, and matrix metalloproteinases in primate arterial smooth muscle cell migration. Arterioscler Thromb Vasc Biol 16:1373-1382.

Kiryushko D, Berezin V, Bock E (2004) Regulators of neurite outgrowth: role of cell adhesion molecules. Ann N Y Acad Sci 1014:140-154

Kristensen P, Hougaard DM, Nielsen LS, Dano K (1986) Tissue-type plasminogen activator in rat adrenal medulla. Histochemistry 85:431-436.

Lander AD, Fujii DK, Reichardt LF (1985) Laminin is associated with the "neurite outgrowth-promoting factors" found in conditioned media. Proc Natl Acad Sci U S A 82:2183-2187.

Liu Y, Fallon L, Lashuel HA, Liu Z, Lansbury PT Jr (2002) The UCH-L1 gene encodes two opposing enzymatic activities that affect alpha-synuclein degradation and Parkinson's disease susceptibility. Cell 111:209-218.

McCance SG, Castellino FJ (1995) Contributions of individual kringle domains toward maintenance of the chloride-induced tight conformation of human glutamic acid-1 plasminogen. Biochemistry 34:9581-9586.

Menhart N, Hoover GJ, McCance SG, Castellino FJ (1995) Roles of individual kringle domains in the functioning of positive and negative effectors of human plasminogen activation. Biochemistry 34:1482-1488.

Miles LA, Dahlberg CM, Plow EF (1988) The cell-binding domains of plasminogen and their function in plasma. J Biol Chem 263:11928-11934.

Miles LA, Hawley SB, Baik N, Andronicos NM, Castellino FJ, Parmer RJ (2005) Plasminogen receptors: the sine qua non of cell surface plasminogen activation. Front Biosci 10:1754-1762.

Molinari F, Rio M, Meskenaite V, Encha-Razavi F, Auge J, Bacq D, Briault S, Vekemans M, Munnich A, Attie-Bitach T, Sonderegger P, Colleaux L (2002) Truncating neurotrypsin mutation in autosomal recessive nonsyndromic mental retardation. Science 298:1779-1781.

Parmer RJ, Mahata M, Mahata S, Sebald MT, O'Connor DT, Miles LA (1997) Tissue plasminogen activator (t-PA) is targeted to the regulated secretory pathway: catecholamine storage vesicles as a reservoir for the rapid release of t-PA. J Biol Chem 272:1976-1982.

Pietri T, Eder O, Breau MA, Topilko P, Blanche M, Brakebusch C, Fassler R, Thiery JP, Dufour S (2004) Conditional betal-integrin gene deletion in neural crest cells causes severe developmental alterations of the peripheral nervous system. Development 131:3871-3883.

Pittman RN, DiBenedetto AJ (1995) PC12 cells overexpressing tissue plasminogen activator regenerate neurites to a greater extent and migrate faster than control cells in complex extracellular matrix. J Neurochem 64:566-575.

Powell SK, Williams CC, Nomizu M, Yamada Y, Kleinman HK (1998) Laminin-like proteins are differentially regulated during cerebellar development and stimulate granule cell neurite outgrowth in vitro. J Neurosci Res 54:233-247.

Pozzi A, Wary KK, Giancotti FG, Gardner HA (1998) Integrin alphalbetal mediates a unique collagen-dependent proliferation pathway in vivo. J Cell Biol 142:587-594.

Pozzi A, Moberg PE, Miles LA, Wagner S, Soloway P, Gardner HA (2000) Elevated matrix metalloprotease and angiostatin levels in integrin alpha 1 knockout mice cause reduced tumor vascularization. Proc Natl Acad Sci U S A 97:2202-2207.

Qian Z, Gilbert ME, Colicos MA, Kandel ER, Kuhl D (1993) Tissue-type plasminogen activator is induced as an immediate-early gene during seizure, kindling and long-term potentiation. Nature 361:453-457.

Sappino AP, Madani R, huarte J, Belin D, Kiss JZ, Wohlwend A, Vassalli JD (1993) Extracellular proteolysis in the adult murine brain. J Clin Invest 92:679-685.

Schott D, Dempfle CE, Beck P, Liermann A, Mohr-Pennert A, Goldner M, Mehlem P, Azuma H, Schuster V, Mingers AM, Schwarz HP, Kramer MD (1998) Therapy with a purified plasminogen concentrate in an infant with ligneous conjunctivitis and homozygous plasminogen deficiency. N Engl J Med 339:1679-1686.

Seeds NW, Basham ME, Haffke SP (1999) Neuronal migration is retarded in mice lacking the tissue plasminogen activator gene. Proc Natl Acad Sci U S A 96:14118-14123.

Siconolfi LB, Seeds NW (2001a) Induction of the plasminogen activator 
system accompanies peripheral nerve regeneration after sciatic nerve crush. J Neurosci 21:4336-4347.

Siconolfi LB, Seeds NW (2001b) Mice lacking tPA, uPA, or plasminogen genes showed delayed functional recovery after sciatic nerve crush. J Neurosci 21:4348-4355.

Takahashi H, Uno S, Watanabe Y, Arakawa K, Nakagawa S (2000) Expression of nerve growth factor-induced type 1 plasminogen activator inhibitor (PAI-1) mRNA is inhibited by genistein and wortmannin. Neuroreport 11:1111-1115.

Tarui T, Miles LA, Takada Y (2001) Specific interaction of angiostatin with integrin alpha vbeta 3 in endothelial cells. J Biol Chem 276:39562-39568.

Tran PB, Miller RJ (2003) Chemokine receptors: signposts to brain development and disease. Nat Rev Neurosci 4:444-455.

Tsirka SE, Bugge TH, Degen JL, Strickland S (1997) Neuronal death in the central nervous system demonstrates a non-fibrin substrate for plasmin. Proc Natl Acad Sci U S A 94:9779-9781.

Vassar R (2002) Beta-secretase (BACE) as a drug target for Alzheimer's disease. Adv Drug Deliv Rev 54:1589-1602.

Vuolteenaho R, Nissinen M, Sainio K, Byers M, Eddy R, Hirvonen H, Shows TB, Sariola H, Engvall E, Tryggvason K (1994) Human laminin M chain (merosin): complete primary structure, chromosomal assignment, and expression of the $\mathrm{M}$ and $\mathrm{A}$ chain in human fetal tissues. J Cell Biol 124:381-394.

Waisman DM (2003) Plasminogen: structure, activation, and regulation. New York: Klewer Academic/Plenum Publishers.

Zhang L, Seiffert D, Fowler B, Jenkins GR, Thinnes T, Loskutoff DJ, Parmer RJ, Miles LA (2002) Plasminogen has a broad extrahepatic distribution. Thromb Haemost 87:493-501. 